\title{
Bromophenol concentrations in fish from Salvador, BA, Brazil
}

\author{
ALINE S. OLIVEIRA ${ }^{3}$, VILMA M. SILVA ${ }^{1}$, MÁRCIA C.C. VELOSO ${ }^{2}$, \\ GISLAINE V. SANTOS ${ }^{3}$ and JAILSON B. DE ANDRADE ${ }^{1}$ \\ ${ }^{1}$ Instituto de Química, Universidade Federal da Bahia, UFBA, Rua Barão de Geremoabo s/n \\ Campus Universitário de Ondina, 40170-290 Salvador, BA, Brasil \\ ${ }^{2}$ Centro Federal de Educação Tecnológica da Bahia, CEFET-BA, Rua Emídio dos Santos s/n \\ Barbalho, 40625-650 Salvador, BA, Brasil \\ ${ }^{3}$ Instituto de Biologia, Universidade Federal da Bahia, UFBA, Rua Barão de Geremoabo s/n \\ Campus Universitário de Ondina, 40170-290 Salvador, BA, Brasil \\ Manuscript received on July 14, 2008; accepted for publication on October 7, 2008; \\ contributed by JAILSON B. DE ANDRADE*
}

\begin{abstract}
The main objective of this work is to evaluate the occurrence of bromophenols (2-bromophenol, 4-bromophenol, 2,4dibromophenol, 2,6-dibromophenol and 2,4,6-tribromophenol), in the flesh and guts in two species of the Lutjanidae Family: Lutjanus synagris and Ocyurus chrysurus. The bromophenols were extracted by steam distillation with pentaneether $(7: 3 \mathrm{v} / \mathrm{v})$, identified by reverse phase High Performance Liquid Chromatography (HPLC-UV), and quantified by the external-standard method. Total bromophenol concentrations were similar in the muscle of both species, ranging from $36 \mathrm{ng} \mathrm{g}^{-1}$ to $349 \mathrm{ng} \mathrm{g}^{-1}$. The total bromophenol concentrations in stomach (ranging from $12 \mathrm{ng} \mathrm{g}^{-1}$ to $586 \mathrm{ng} \mathrm{g}^{-1}$ ) were slightly higher than in muscle. The presence of bromophenol in the muscles of the species under study may occur as a result of their diet. The results of this work are therefore expected to contribute toward a better understanding of the path of bromophenol absorption from the fish's stomach to the rest of its body.
\end{abstract}

Key words: bromophenols, flavor, marine fishes, Lutjanus, Ocyurus .

\section{INTRODUCTION}

Flavor, or the consumer's perception thereof, is an important attribute of the quality of marine fishes and other seafoods (Lindsay 1990, Stansby 1962), and is the first and principal discriminative factor in his evaluation, acceptance, rejection or preference for the product (Boyle et al. 1992a). This fact has led to extensive research in several areas, including agriculture and the food and beverage industry, aimed at putting on the market products of excellent nutritional quality and especially of pleasant flavor (Lindsay 1990).

The success of aquaculture products has been hampered by problems relating to the quality of their flavor,

\footnotetext{
* Member Academia Brasileira de Ciências Correspondence to: Jailson B. de Andrade E-mail: jailsong@ufba.br
}

since many consumers can clearly distinguish the difference between the flavor of cultivated and wild harvest seafoods (Boyle et al. 1992a). Knowledge of the factors and chemical substances that determine flavor can contribute significantly to the improvement and expansion of aquaculture and to the preservation, storage, control and improved quality of seafoods.

However, there is still a paucity of information about the specific substances that give fishes and other seafoods their widely diverse flavors and other subtle differences. In the last few decades, a group of organic compounds called simple bromophenols has been considered the main component of the flavor of several seafoods (Boyle et al. 1992b, 1993, Silva et al. 2007, Whitfield et al. 1992a, Whitfield 1988). These compounds, including 2-bromophenol (2-BP), 4-bromo- 
phenol (4-BP), 2,4-dibromophenol (2,4-DBP), 2,6dibromophenol (2,6-DBP) and 2,4,6-tribromophenol (2,4,6-TBP), (Fig. 1) in water, have very low sensory threshold concentrations in the $\mathrm{ng} \mathrm{g}^{-1}$ range (Whitfield 1988).
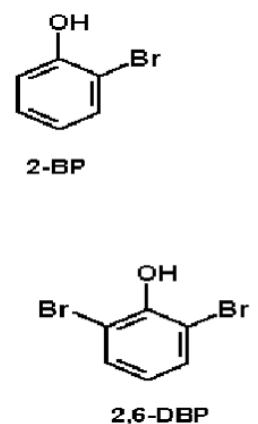
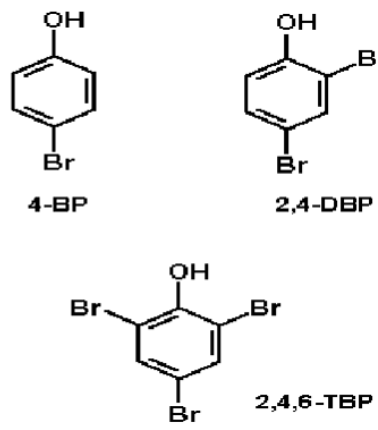

Fig. 1 - Simple bromophenols: 2-bromophenol (2-BP); 4-bromophenol (4-BP); 2,4-dibromophenol (2,4-DP); 2,6-dibromophenol (2,6DP) and 2,4,6-tribromophenol (2,4,6-TBP).

Bromophenols, which have been found in marine fishes (Boyle et al. 1992a, Whitfield et al. 1998), crustaceans (Chung et al. 2003a, Whitfield et al. 1997, 2002) and mollusks (Boyle et al. 1992a), are strongly associated with pleasant (marine- or ocean-like) or unpleasant (plastic-, medicinal-, disinfectant-, iodoform or iodinelike) flavors, alone or in different combinations and concentrations. Marine food gourmets describe the flavor of some fish species as mildly candy-like and others as marine or oceanic-like, which is characteristic of the presence of bromophenols in different concentrations (Whitfield et al. 1998). Boyle et al. (1992a), who compared four Pacific salmon species (Oncorhynchus spp) from marine and freshwater environments, found that

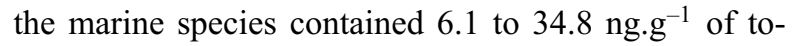
tal bromophenols while the freshwater species not only contained none of the five bromophenols investigated but also had none of the characteristic oceanic-like flavor. Although 2,4-DBP and especially 2,4,6-TBP have been considered important anthropic pollutants (playing an important role as industrially produced flame retardant and pesticides) (Polo et al. 2006), the presence of bromophenols in these marine organisms has been attributed to their natural diets; in other words, these compounds may come from other species in the food chain. Despite of their importance does not exists limit value to the bromophenol content in marine species.
According to previous studies, bromophenols have been detected in a variety of other marine organisms such as macroalgae (Chung et al. 2003b, Lee et al. 2007, Pedersén et al. 1974, Phillips and Towers 1981, Whitfield et al. 1992b, 1999a, Xu et al. 2003), polychaetes (Goerke and Weber 1990, 1991, Steward and Lovell 1997, Whitfield et al. 1999b), sponges (Hattori et al. 2001, Unson et al. 1994, Vetter and Janussen 2005) and bryozoans (Whitfield et al. 1999b), which are a major dietary source for many marine organisms including fish (Whitfield et al. 1997, 1998, 1999a, 1999b, Ma et al. 2005).

The flavor of marine fishes varies depending on the location and time of year when they were caught (Whitfield et al. 1995), and the diet of certain fish species can vary considerably according to the availability of alimentary components, which depends on seasonal variations (Whitfield et al. 1998). It is believed that the bromophenols in marine fish come from their natural diet (Whitfield et al. 1998). This hypothesis is strongly supported by the fact that bromophenols have been detected in the stomach content and the flesh, with higher concentrations in the former (Chung et al. 2003a, Whitfield et al. 1995), allied to the fact that benthic carnivorous fishes feeding on polychaetes and herbivorous fishes feeding on macroalgae have a strong flavor while piscivorous fishes feeding primarily on other fish do not contain these bromophenols (Whitfield et al. 1994, 1995, 1996).

However, the identification of specific organisms that may introduce bromophenols into the diet of marine fish requires a broader investigation (Whitfield et al. 1996, 1998). Some reports suggest that fish do not accumulate bromophenols, but gradually metabolize or excrete them (Whitfield et al. 1992b, Anthoni et al. 1990). Therefore, studies are needed to establish the route whereby bromophenols are transferred to different fish species.

Fish is a staple food among coastal populations in the state of Bahia. Standing out among the most popular fish species are the members of the Lutjanidae family (popularly known as "red"), which are highly valued and widely accepted by the consumer market of the city of Salvador. Nevertheless, few studies have focused on the chemistry of these species, particularly with regard to the volatile organic compounds (VOCs) that give these 
species their particular flavor (Santos et al. 2001, Veloso et al. 2001). The purpose of this work was therefore to evaluate the occurrence of bromophenols in the flesh and guts (stomach content and pyloric ceca or appendices) of two species of the Lutjanidae family, Lutjanus synagris and Ocyurus chrysurus, and to identify the probable alimentary source of these bromophenols in these species.

\section{MATERIALS AND METHODS}

\section{Solvents, REAGENTS AND StANDARDS}

The bromophenols standards were obtained from Aldrich (Milwaukee, WI), in purities ranging from 97 to $99 \%$. Purified water was obtained by distillation and filtration through an E-pure Alltech system (Deerfield, IL). Acetonitrile (HPLC grade) was obtained from Aldrich and filtered through a $0.45 \mu \mathrm{m}$ membrane. The other reagents (pentane, diethyl ether, sodium chloride and sulfuric acid) were of analytical grade produced by Merck (Darmstadt, Germany).

\section{Collection and Preparation of SAmples}

Two fish species of the Lutjanidae family were studied: Lutjanus synagris and Ocyurus chrysurus. Fresh fish caught in the coastal waters of Bahia, Brazil $\left(13^{\circ} 01^{\prime} \mathrm{S}\right.$ and $38^{\circ} 31^{\prime} \mathrm{W}$ ), were purchased from commercial fishermen. Three specimens of each species were purchased, with an average weight of $1.0 \mathrm{~kg}$ and $30 \mathrm{~cm}$ length. In the laboratory, the fish were washed in distilled water, gutted, and the flesh was separated from the heads, tails, and backbone.

The flesh was washed in a saturated $\mathrm{NaCl}$ solution and then blended into a smooth purée in a food processor (Triton-Arno). Samples of puréed flesh (in portions of $250 \mathrm{~g}$ ) were stored in sealed polyethylene bags at $-15^{\circ} \mathrm{C}$ prior to their analysis.

The guts (full stomach contents and pyloric ceca) were dissected, weighed and stored in a refrigerator $\left(0^{\circ} \mathrm{C}\right)$. Subsequently, an incision was made in each stomach to check the types of food items and classify them according to the highest taxon. This material and the pyloric ceca were then blended together into a purée. Stomachs that were empty, everted, or contained baitlike contents were rejected. The samples consisting of three blended stomachs, each weighing about $30 \mathrm{~g}$, were stored in sealed polyethylene bags at $-15^{\circ} \mathrm{C}$ until required for analysis.

\section{PREPARATION OF BROMOPHENOL STANDARDS AND CALIBRATION SOLUTIONS}

Stock solutions (100 $\left.\mathrm{mg} \mathrm{mL}^{-1}\right)$ were prepared by first weighing each bromophenol and then dissolving it in acetonitrile. The standard calibration solutions were prepared by diluting the bromophenol stock solutions in acetonitrile, in concentrations of 200 to $1000 \mathrm{ng} \mathrm{mL}^{-1}$. The resulting solutions were stored at $4^{\circ} \mathrm{C}$ in dark glass flasks. The standard solutions were prepared at least once a week. More detailed information is available elsewhere (Silva et al. 2005).

\section{EXTRACTION OF BROMOPHENOLS}

Representative samples of flesh $(250 \mathrm{~g})$ or guts $(30 \mathrm{~g})$ were homogenized separately in purified water $(1000 \mathrm{~mL})$ and the homogenates, acidified to $\mathrm{pH}$ 1 with $10 \mathrm{~mol} \mathrm{~L}^{-1}$ sulfuric acid, were left to stand at ambient temperature $\left(26 \pm 3^{\circ} \mathrm{C}\right)$ for about $12 \mathrm{~h}$. The volatile components were isolated by combined continuous hydrodistillation-solvent extraction with $2 \mathrm{~mL}$ of pentane/diethyl ether (6:4) using a modified Clevenger apparatus (Vidrosel Ltda, Brazil) adapted for this study (Silva et al. 2005). The hydrodistillation process was completed after 4 hours, and the $\mathrm{pH}$ of the residues was measured. The collected extract was concentrated under a gentle stream of ultrahigh purity $(99.999 \%)$ nitrogen. The concentrated extract was then dissolved in acetonitrile $(500 \mu \mathrm{L})$ and stored in $2 \mathrm{~mL}$ dark glass vials at $-15^{\circ} \mathrm{C}$ until it was analyzed.

\section{SEPARATION OF COMPOUNDS}

A PerkinElmer series 200 liquid chromatograph equipped with a Rheodyne (Cotati, California, USA) injector valve with a $20 \mu \mathrm{L}$ sample loop and a PerkinElmer UV-visible detector were used. Chromatographic separation of bromophenols was performed in a LiChrospher $100 \mathrm{Rp}-18$ (244 mm $\times 4.4 \mathrm{~mm}$ I.D., $5 \mu \mathrm{m}$; Merck) column coupled to a LiChrospher guard column with similar characteristics $(14 \mathrm{~mm} \times 4 \mathrm{~mm}$ I.D.; Merck). The mobile phase vacuum-degassed in a sonicator was a mixture of water:acetonitrile pumped in gradient mode (Table I) at a flow rate of $1.0 \mathrm{~mL} \mathrm{~min}^{-1}$ at ambient tem- 
perature. The detection was performed at $286 \mathrm{~nm}$, where the 2-BP, 4-BP, 2,4- and 2,6-DBP show significant absorptive values and at $297 \mathrm{~nm}$ for $2,4,6-$ TBP.

TABLE I

RP-HPLC solvent gradient varying the mobile phase water-acetonitrile composition used in the bromophenols separation.

\begin{tabular}{c|c|c}
\hline Time (min) & $\begin{array}{c}\text { Solution with } \\
45 \% \mathrm{CH}_{3} \mathrm{CN}: 55 \% \mathrm{H}_{2} \mathrm{O}\end{array}$ & $\% \mathrm{CH}_{3} \mathrm{CN}$ \\
\hline 0 & 100 & 0 \\
\hline 10 & 100 & 0 \\
\hline 20 & 45 & 55 \\
\hline 22 & 45 & 55 \\
\hline 27 & 100 & 0 \\
\hline
\end{tabular}

\section{ANALyTiCAl CALIBRATION CURVE AND QUANTIFICATION}

Analytical calibration curves were built by plotting the observed peak height against the amount of injected bromophenol (200 to $1000 \mathrm{ng} \mathrm{mL}^{-1}$ ). Quantification of the bromophenols was performed using an external standard $(\mathrm{n}=5)$, by measuring the peak height at each retention time calculated from the calibration curve. Spikes of each bromophenol were produced in the samples to ascertain the exact retention times. The total bromophenol content (TBC), used in the literature to reflect the impact of flavor produced by all the bromophenols contained in a food (Whitfield et al. 1995, 1996, 1998), was calculated by incrementing the concentration ( $\mathrm{ng} \mathrm{g}^{-1}$ ) of all the simple bromophenols detected in a sample.

\section{RESULTS AND DISCUSSION}

The items found in the stomach contents of the specimens indicated that the main taxonomic categories were Crustacea (Decapoda) and Teleostei, with a smaller proportion of representatives of the taxon Mollusca. When full, the pyloric appendices or pyloric ceca presented a stomach fluid, probably due to a previous digestion. The five simple bromophenols were found to occur in the muscle and stomach of the species under study. Tables II and III list the concentration of each of the five bromophenols and the total bromophenol content (TBC) found, respectively, in the muscle and stomach of each species.
The highest bromophenol concentrations in the two fish species involved 2,4-DBP and 2,4,6-TBP, which were present in concentrations exceeding $110 \mathrm{ng} \mathrm{g}^{-1}$ in muscle and stomach (Tables II and III). 2-BF and 4-BF showed the lowest concentrations.

Total bromophenol concentrations showed a similar predominance in the muscle of both species, ranging from $36 \mathrm{ng} \mathrm{g}^{-1}$ to $349 \mathrm{ng} \mathrm{g}^{-1}$ (Table II). The total concentrations in the stomach (ranging from $12 \mathrm{ng} \mathrm{g}^{-1}$ to $586 \mathrm{ng} \mathrm{g}^{-1}$ ) (Table III ) were slightly higher than in the muscle.

The results presented in Table II are consistent with those found by Whitfield (1998, 1999), Chung et al. (2003a) and Silva et al. (2005) in marine fish. Those authors reported high total bromophenol concentrations (2.72 to $462 \mathrm{ng} \mathrm{g}^{-1}$ ), especially for 2,4,6-TBP, which was the most frequent and abundant bromophenol (Chung et al. 2003a, Silva et al. 2005). The concentrations of 2,6-DBP, 2,4-DBP and 2,4,6-TBP determined in seven fish species (Branchiostegus wardi, Girella tricuspidata, Nemadactylus douglassi, Rhabdosargus sarba, Acanthopagrus australis, Meuschenia trachylepis, and Pseudorhombus jenynsii) (Parejo et al. 2004) fell within the range of 0.4-18 $\mathrm{ng} \mathrm{g}^{-1}, 112-150 \mathrm{ng} \mathrm{g}^{-1}$ and 5.7-170 $\mathrm{ng} \mathrm{g}^{-1}$, respectively. The concentrations reported here (Table II) show a similar predominance of these three bromophenols in the two fish species studied.

In the muscle of the species Lutjanus synagris, 2,4DBF (110 $\mathrm{ng} \mathrm{g}^{-1}$ ) and 2,4,6-TBF (171 $\mathrm{ng} \mathrm{g}^{-1}$ ) stood out, particularly in the specimens collected in winter, as indicated in Table II and showed in the Figure 2. The muscle of the species Ocyurus chrysurus showed similar results, i.e., 2,4-DBF (158 $\left.\mathrm{ng} \mathrm{g}^{-1}\right)$ and 2,4,6TBF (119 $\mathrm{ng} \mathrm{g}^{-1}$ ) (Table II). The analysis of bromophenol in the stomach also showed a predominance of 2,4DBF and 2,4,6-TBF in both species, although the species O. chrysurus showed significant concentrations of 2,6DBF as well (Table III). The higher bromophenol concentrations found in the specimens collected in winter were consistent with the greater abundance and weight of L. synagris and O. chrysurus (Costa et al. 2002) in autumn and winter. Low temperature seasons are associated with the growth cycle of marine species (Chung et al. 2003a, b). The abundance and weight, as well the bromophenol content, decrease in summer. 
TABLE II

Range of bromophenol concentrations $\left(\mathrm{ng} \mathrm{g}^{-1}\right)$ found in muscle.

\begin{tabular}{c|c|c|c|c|c|c}
\hline Fish $(\mathrm{N}=15)$ & $2-\mathrm{BF}$ & $4-\mathrm{BF}$ & $2,4-\mathrm{DBF}$ & $2,6-\mathrm{DBF}$ & $2,4,6-\mathrm{TBF}$ & $\mathrm{TBC}$ \\
\hline Lutjanus synagris & $1-35$ & $\mathrm{nd}-20$ & $11-110$ & $3-29$ & $15-171$ & $41-349$ \\
\hline Ocyurus chrysurus & $0.20-19$ & $\mathrm{nd}-14$ & $7-158$ & $\mathrm{nd}-28$ & $6-119$ & $36-299$ \\
\hline
\end{tabular}

2-BF: 2-bromophenol, 4-BF: 4-bromophenol, 2,4-DBF: 2,4-dibromophenol, 2,6-DBF: 2,6-dibromopheno; 2,4,6-TBF: 2,4,6-tribromophenol; TBC = Total Bromophenol Concentration; nd = not detected.

TABLE III

Range of bromophenol concentrations $\left(\mathrm{ng} \mathrm{g}^{-1}\right)$ in stomach.

\begin{tabular}{c|c|c|c|c|c|c}
\hline Fish (N=9) & $2-\mathrm{BF}$ & $4-\mathrm{BF}$ & $2,4-\mathrm{DBF}$ & $2,6-\mathrm{DBF}$ & $2,4,6-\mathrm{TBF}$ & $\mathrm{TBC}$ \\
\hline Lutjanus synagris & $\mathrm{nd}-6$ & $\mathrm{nd}-11$ & $7-247$ & $\mathrm{nd}-27$ & $3-104$ & $12-396$ \\
\hline Ocyurus chrysurus & $\mathrm{nd}-14$ & $\mathrm{nd}-8$ & $98-372$ & $\mathrm{nd}-214$ & $\mathrm{nd}-55$ & $179-586$ \\
\hline
\end{tabular}

2-BF: 2-bromophenol, 4-BF: 4-bromophenol, 2,4-DBF: 2,4-dibromophenol, 2,6-DBF: 2,6-dibromophenol; 2,4,6-TBF: 2,4,6-tribromophenol; $\mathrm{TBC}=$ Total Bromophenol Concentration; $\mathrm{nd}=$ not detected.
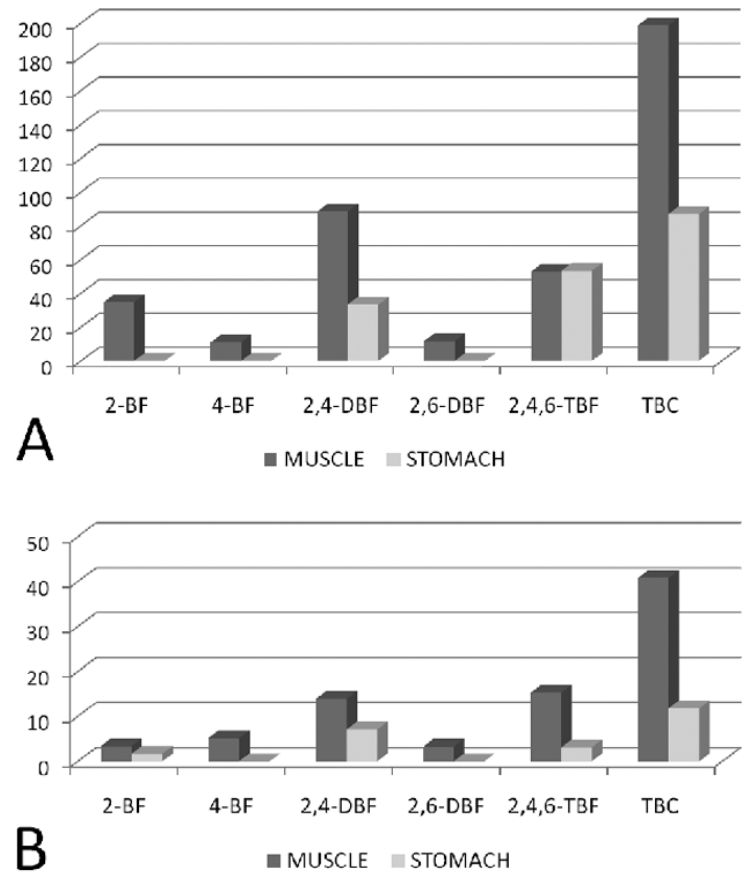

Fig. 2 - Bromophenol concentrations and TBCs in the muscle and stomach of L. synagris collected in winter (A) and summer time (B).

Figures 3 and 4 indicate, respectively, the variation in average bromophenol concentrations and TBCs in the muscle (15 samples) and stomach (9 samples) of the species L. synagris and $O$. chrysurus during the period of this study. With the exception of 2,4-BF, the bromophenol pattern found for Lutjanus synagris was similar in the muscle and stomach (Fig. 3). In contrast, O. chrysurus showed substantial differences, especially in 2,4-BF, 2,6-BF and TBF (Fig. 4), which were found predominantly in the stomach.

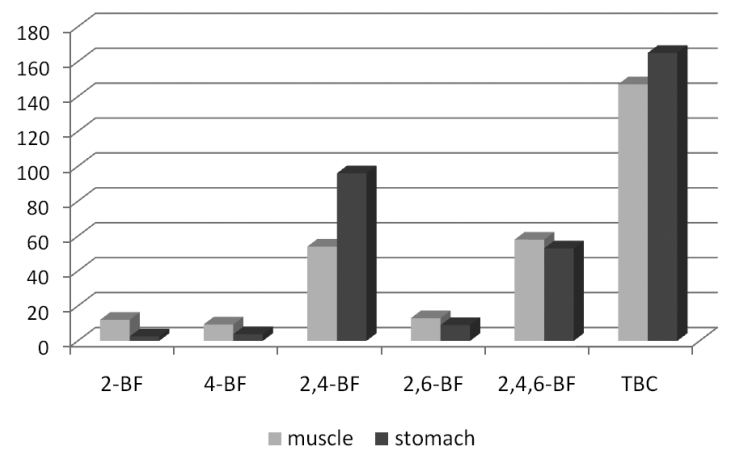

Fig. 3 - Average bromophenol concentrations and TBCs in the muscle and stomach of L. synagris.

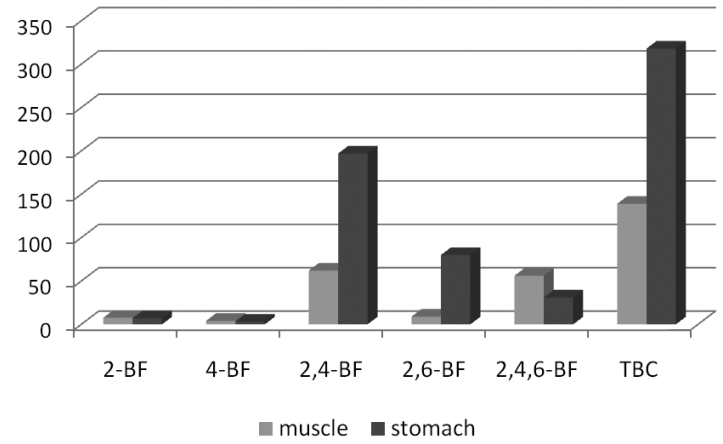

Fig. 4 - Average bromophenol concentrations and TBCs in the muscle and stomach of $O$. chrysurus. 
The predominant items in the diet of L. synagris and $O$. chrysurus are crustaceans (mainly Decapoda) and fish, and a smaller proportion of mollusks and polychaetes (Costa et al. 2002, Druzhinin 1970, Szpilman 1991, Filho 1994, La Morinière et al. 2003). With the exception of polychaetes, the stomach contents of the specimens collected were compatible with those reported in the literature. Thus, the bromophenol found in the muscle of the species under study may come from their diets.

The route of bromophenol absorption from the fish's stomach to the rest of its body, as well as its physiological roles, is still unknown (Boyle et al. 1992b, Chung et al. 2003b). Additional research is therefore necessary to clarify such questions, whose answers are of paramount importance for aquaculturists.

\section{ACKNOWLEDGMENTS}

The present work was supported by the Conselho Nacional de Desenvolvimento Científico e Tecnológico (CNPq), Fundação de Apoio a Pesquisa do Estado da Bahia (FAPESB)-PRONEX/FAPESB/CNPq, Coordenação de Formação de Pessoal de Nível Superior (CAPES) and Financiadora de Estudos e Projetos (FINEP).

\section{RESUMO}

O principal objetivo do presente trabalho foi o estudo de bromofenóis (2-bromofenol, 4-bromofenol, 2,4-dibromofenol, 2,6-dibromofenol and 2,4,6-tribromofenol), no músculo e estômago de duas espécies de peixes da Familia Lutjanidae: Lutjanus synagris e Ocyurus chrysurus. Os bromofenóis foram extraídos através de destilação por arraste a vapor com pentanoéter $(7: 3 \mathrm{v} / \mathrm{v})$, analisados por Cromatografia Líquida de Alta Eficiência e quantificados por padronização externa. As concentrações totais de bromofenóis no músculo de ambas as espécies foram similares e estiveram na faixa de $36 \mathrm{ng} \mathrm{g}^{-1}$ a $349 \mathrm{ng} \mathrm{g}^{-1}$. As concentrações totais de bromofenóis no estômago (na faixa de $12 \mathrm{ng} \mathrm{g}^{-1}$ a $586 \mathrm{ng} \mathrm{g}^{-1}$ ) foram mais altas que no músculo. A presença de bromofenóis no músculo das espécies estudadas pode ter origem na dieta. Os resultados deste trabalho contribuirão para o melhor entendimento das rotas de absorção de bromofenóis nos peixes.

Palavras-chave: bromofenóis, flavor, peixes marinhos, Lutjanus, Ocyurus.

\section{REFERENCES}

Anthoni U, Larsen C, Nielsen PH And ChristoPHERSEN C. 1990. Off-flavor from commercial crustaceans from North Atlantic zone. Biochem Syst Ecol 18: $377-379$.

Boyle JL, Lindsay RC AND Stuiber DA. 1992a. Bromophenol distribution in salmon and selected seafoods of fresh and saltwater origin. J Food Sci 57: 918-922.

Boyle JL, Lindsay RC AND StUIBER DA. 1992b. Contributions of bromophenols to marine-associated flavors of fish and seafood. J Aquat Food Prod Technol 1: 43-63.

Boyle JL, Lindsay RC AND Stuiber DA. 1993. Ocurrence and properties of flavor-related bromophenols found in the marine environment: a review. J Aquat Food Prod Technol 2: 75-112.

Chung HY, Ma WCJ, Ang PO And KIm JS. 2003a. Seasonal distribution of bromophenols in selected Hong Kong seafood. J Agric Food Chem 51: 6752-6760.

Chung HY, MA WCJ, ANG PO, Kim JS AND Chen F. 2003b. Seasonal variations of bromophenols in brown algae (Padina arborescens, Sargassum siliquastrum, and Lobophora variegata) collected in Hong Kong. J Agric Food Chem 51: 2619-2624.

Costa PAS, Braga AC And Rocha LOF. 2002. Reef fisheries in Porto Seguro, eastern Brazilian coast. Fisheries Res 1449: 1-7.

DRUZHININ AD. 1970. The range and biology of snappers (Family Lutjanidae). J Ichthyology 10: 717-736.

FILHO AC. 1994. Peixes da Costa Brasileira. Terceira Edição. São Paulo: Editora Marca d'Água, 304 p.

Goerke H AND Weber K. 1990. Locality-dependent concentrations of bromophenols in Lanice conchilega (Polychaeta: Terebellidae). Comp Biochem Physiol 97B: 741-744.

Goerke H AND WeBer K. 1991. Bromophenols in Lanice conchilega (Polychaeta: Terebellidae) - The influence of sex, weight and season. Bull Mar Sci 44: 70-74.

HATTORI T, KONNO A, ADACHI K AND ShiURI Y. 2001. Four new bioactive bromophenols from the palauan sponge Phyllospongia dendyi. Fisheries Sci 67: 899-903.

LA Morinière EC, Pollux BJA, NAGElKerken I AND VAN DER VELDE G. 2003. Diet shifts of Caribbean grunts (Haemulidae) and snappers (Lutjanidae) and the relation with nursery-to-coral reef migrations. Estuar Coast Shelf S 57: 1-11. 
Lee H, Lee T, Lee J, Chae C, Chung S, Shin D, Shin J AND OH K. 2007. Inhibition of the Pathogenicity of Magnaporthe grisea by Bromophenols, Isocitrate Lyase Inhibitors, from the Red Alga Odonthalia corymbifera. J Agric Food Chem 55: 6923-6928.

LINDSAY RC. 1990. Fish flavors. Food Rev Int 6: 437-455.

MA JW, Chung HY, ANG PO AND Kim J. 2005. Enhancement of Bromophenol Levels in Aquacultured Silver Seabream (Sparus sarba).J Agric Food Chem 53: 2133 2139.

Parejo I, Viladomat F, Bastida J and Codine C. 2004. Development and validation of a high-performance liquid chromatographic method for the analysis of antioxidative phenolic compounds in fennel using a narrow bore reversed phase C18 column. Anal Chim Acta 512: 271.

Pedersén M, Saenger P ANd Fries L. 1974. Simple brominated phenols in red algae. Phytochemistry 13: 2273-2279.

PhILlips DW AND Towers GHN. 1981. Bromophenols of Rhodomela larix: Chemotaxonomy of morphological forms. Biochem Syst Ecol 9: 1-3.

Polo M, Llompart M, Garcia-Janes C, Gomez-Noya G, Bollain M And Cela R. 2006. Development of a solid-phase microextraction method for the analysis of phenolic flame retardants in water samples. J Chromatogr A 1124: 11-21.

Santos GV, Veloso MCC, Pereira PAP And DE ANDRADE JB. 2001. Fish off-flavor analysis by headspace and off-line purge and trap by high resolution gas chromatography coupled with mass spectrometry detector. Am Lab 24: 28-30.

Silva VM, Veloso MCC, Oliveira As, SAntos GV, PereirA PAP AND DE ANDRADE JB. 2005. Determination of simple bromophenols in marine fishes by reverse-phase high performance liquid chromatography (RP-HPLC). Talanta 68: 323-328.

Silva VM, Lopes WA, de Andrade JB, Veloso MCC, SANTOS GV AND Oliveira AS. 2007. Bromofenóis Simples relacionados ao "Flavor" de Organismos Marinhos. Quim Nova 30: 629-635.

STANSBY ME. 1962. Speculations on Fish Odors and Flavors. Food Technol Feature 4: 28-32.

Steward CC AND LOVEll C R. 1997. Respiration and assimilation of 4-bromophenol by estuarine sediment bacteria. Microb Ecol 33: 198-205.
SzPilman M. 1991. Guia Aqualung de Peixes - Guia Prático de Identificação dos Peixes do Litoral Brasileiro, 220 p.

Unson MD, Holland ND AND FAULKNeR DJ. 1994. A brominated secondary metabolite synthesized by the cyanobacterial symbiont of a marine sponge and accumulation of the crystalline metabolite in the sponge tissue. Mar Biol 119: 1-11.

Veloso MCC, Silva VM, Santos GV And DE AndraDE JB. 2001. Determination of aldehydes in fish by highperfomance liquid chromatography. J Chromatogr Sci 39: 173-176.

Vetter W AND JANUSSEN D. 2005. Halogenated natural products in five species of antartic sponges: compounds with POP-like properties? Environ Sci Technol 39: 38893895 .

Whitfield FB. 1988. Chemistry of off-flavours in marine organisms. Water Sci Technol 20: 63-74.

Whitfield FB, Shaw KJ And Walker DI. 1992a. The source of 2,6-dibromophenol: Cause of an iodoform taint in Australian prawns. Water Sci Technol 25: 131-138.

Whitfield FB, Shaw KJ And Svoronos D. 1992b. The volatile aroma components of Australian marine algae. In: $12^{\text {th }}$ InTERNATIONAL CONGRESS OF FLAVOURS, FrAGRANCES AND ESSENTIAL OILS, Vienna. Abstracts, Vienna, 365-372.

Whitfield FB, Shaw K And Svoronos D. 1994. Effect of the natural environment on the flavour of seafoods: the flavour of Girella tricuspidata. In: TRENDS IN FLAVOUR RESEARCH, p. 417-420.

Whitfield FB, Helidoniotis F, Shaw KJ, Svoronos D AND FORD GL. 1995. The source of bromophenols in some species of Australian ocean fish. Water Sci Technol 31: 113-120.

Whitfield FB, Helidoniotis F AND DREW M. 1996. The role of diet and environment in the natural flavours of seafoods. In Flavour Science: Recents Developments. TAYlor AJ, Motram DS (Eds), Cambridge, U.K.: The Royal Society of Chemistry: Cambridge, U.K. p 3-12.

Whitfield FB, Helidoniotis F, Shaw KJ AND SvoRONOS D. 1997. Distribution of bromophenols in Australian wild-harvested and cultivated prawns (shrimp). J Agric Food Chem 45: 4398-4405.

Whitfield FB, Heliodoniotis F, Shaw KJ ANd SvoRONOS D. 1998. Distribution of bromophenols in species of ocean fish from eastern Australia. J Agric Food Chem 46: $3750-3757$. 
Whitfield FB, Helidoniotis F, Shaw KJ and SvoRONOS D. 1999a. Distribution of bromophenols in species of marine algae from eastern Australia. J Agric Food Chem 47: 2367-2373.

Whitfield FB, Drew M, Helidoniotis F And SVoRONOS D. 1999b. Distribution of bromophenols in species of marine polychaetes and bryozoans from eastern Australia and the role of such animals in the flavor of edible ocean fish and praws (shrimp). J Agric Food Chem 47: 4756-4762.
Whitfield FB, Helidoniotis F AND Shimth D. 2002. Role of feed ingredients in the bromophenols content of cultured prawn. Food Chem 79: 355-365.

Xu N, Fan X, Yan X, Li X, NiU R and Tseng CK. 2003. Antibacterial bromophenols from the marine red alga Rhodomela confervoides. Phytochemistry 62: 12211224. 